\title{
Characterization of Açaí (E. oleracea) Fruits and its Processing Residues
}

\author{
José Dalton Cruz Pessoa ${ }^{1 *}$, Marcos Arduin ${ }^{2}$, Maria Alice Martins ${ }^{1}$ and José Edmar Urano \\ de Carvalho ${ }^{3}$ \\ ${ }^{1}$ Embrapa Instrumentação Agropecuária; Rua XV de Novembro, 1452; 13560-970; São Carlos - SP - Brasil. \\ ${ }^{2}$ Departamento Botânica; Universidade Federal de São Carlos; Rodovia Washington Luís; km 235; 13565-905; São \\ Carlos - SP - Brasil. ${ }^{3}$ Embrapa Amazônia Oriental; Trav. Dr. Enéas Pinheiro s/n; C. P.: 48; 66095-100; Belém - \\ PA - Brasil
}

\begin{abstract}
The aim of this work was to study the source of the açai residue for its possible commercial applications by characterizing the fruit (fresh and dry mass), and performing an anatomic study of the pericarp from which were identified the origin of the anthocyanins, and fatty acids, and fibers; also the vascular system, its fibers constituents and fibrils were characterized. It was concluded that anthocyanins were located on the epiderm and external parenchyma, and that solids retained on the sieve come from the sclerenchyma, and that the fatty acids come from the storage parenchyma. The vascular tissue was formed by the fibers around $20 \mathrm{~mm}$ length. The length distribution of the fibrils had a mean length of $580 \mu \mathrm{m}$.
\end{abstract}

Key words: fiber; fibril; composite; fatty acid; anthocyanin

\section{INTRODUCTION}

At least three important species of the gender Euterpe can be found in Brazil. There was a large population of E. edulis in the Atlantic Forest, a mono-stemmed palm that for a long period of time was explored for heart-palm extraction. The staggering reduction of the Atlantic Forest to 7\% of its initial area, and the unsustainable exploration of this natural resource almost extinguished $E$. edulis. The second species, E. precatoria, is also mono-stemmed and is found mainly in the middle of the Solimões basin, an important tributary to the Amazon River. The third, E. oleracea, can be found in forms of large populations along the border of the rivers and in the areas periodically flooded by the Amazon river basin, close to the mouth of the rivers. That species is multi-stemmed and for some years, after the almost extinction of E. edulis, it was inordinately explored for heartpalm extraction. Its fruit is an important regional commodity and source of nutrients to the poorest populations (Murrieta et al., 1999). Much effort has been made to find out the sustainable management alternatives (Freckleton et al., 2993) (Nogueira, 2000) (Nogueira and Conceição, 2000). Açaí fruits are almost round, with diameter varying between one and two centimeters, and a smooth external epidermis. Its pericarp is about 1 $\mathrm{mm}$, formed by an external parenchyma, an intermediary sclerenchyma and an internal parenchyma followed by the endocarp and the

*Author for correspondence: dalton@cnpdia.embrapa.br 
tegument of the seed (Paula, 1975). In the internal parenchyma the vascular tissue formed by a monostelic network is present. The vascular system forms a well-packaged fiber layer, partially detachable during fruit processing. The vascular system has been named "fiber bundle" by Aguiar and Mendonça (2003) in a paper about morphoanatomy of the E. precatoria fruit.

Açaí market has grown as a result of current food tendencies: convenience, regionalism (typical products), natural foods (organic), ethics, and functionality. The consumption of açaí, even regionally, is extremely convenient. The beverage can be readily consumed with or without sugar, and can be mixed with other natural foods, such as cereals, and can be served as an emulsion (eaten with spoon) or can be drunk. Açaí forests are abundant along the flood plain in the North of Brazil where palms grow naturally. If extracted in a sustainable manner, it meets ethical requirements. Furthermore, the antioxidant and anti-radical properties of the beverage are well known. When added, for example, to yogurt (10\%, $\mathrm{w} / \mathrm{w})$, it presents characteristics similar to those found in typical commercial yogurt with bilberry juice (Coïsson, 2005).

The açaí beverage is prepared, usually, in the traditional processing manner: a vertical cylinder containing horizontal turning rods and a sieve at the bottom. The fruits are inserted through the upper opening through which the operator slowly adds water, without which the fruit is not depulped. An emulsion is formed in the cylinder that flows through the sieve with the addition of more water. Physicochemical characteristics of the drink, therefore, depend on the volume and influx of water into the cylinder. During the fruit rubbing, part of the fiber layer may be incorporated into the drink, but there is no additional information on this, except that the beverage with dry matter above $19 \%$ has a bitter taste, probably due to the tannins extracted from the core.

The most important fruit produced in the northeast of Pará State (Brazil) is açaí. In 2002, it represented $66 \%$ of all fruits produced, increasing to $76 \%$ the following year. That represented $59 \%$ of the profit of the region on fruit commercialization in 2002, passing to $69 \%$ the following year (Costa et al., 2006). Most of the açaí is consumed regionally, where the market is very robust with a tendency for growth. The Secretary of Agriculture of the State of Pará estimated that the fruit production in 2004 reached 350,000 tons, which was $35 \%$ more than it was in 2003. Particularly in the city of Belém, the consumption was between 120 and 180,000 liters daily. The produced waste $(\sim 85 \%$ of the fruit weight) is composed by the core dispensed after rubbering and parts of the fruit retained on the sieve.

There is another market being created which is based on export. According to the survey, in 2003 it was around US\$ 2,12 millions, and in 2005 it was of at least US\$ 5,49 millions, corresponding to about 2000 to 3000 tons of drink (Santana, 2006). This new industry requires qualified products, which requires additional studies on fruit anatomy, post-harvest process, fruit processing, food science, and waste treatment.

The use of natural fibers such as sisal, jute, wood, pineapple, coconut, and cotton in polymeric composites has received considerable attention recently. This is because they are inexpensive, biodegradable, renewable, and environmentally friendly (Tjong et al., 1999). These newer materials and composites that have both economic and environmental benefits are being considered for application in the automotive, building, furniture, and packaging industries (Mishra et al., 2004). The availability of inexpensive lignocellulosic natural fibers in the tropical countries provides a unique opportunity to explore the possibility of their utilization for the synthesis of inexpensive biodegradable composites for various applications. The primary advantages of using these fibers as reinforcements in polymer composites are: (1) low density, (2) low cost, (3) non-abrasive nature, (4) high filling level possible, (5) low energy consumption, (6) high specific properties, (7) biodegradability, and (8) generating rural/agricultural-based economy (Rowell et al., 2000).

The aim of this paper was to study the source of açaí residues by characterizing the fruit (fresh and dry mass), and performing an anatomic study of the pericarp from which were identified the origin of the anthocyanins, and fatty acids, and fibers, and by characterizing the vascular system: fibers constituents and fibrils length. 


\section{MATERIAL AND METHODS}

\section{Fruit mass, and its parts. Fresh mass}

The mass of 60 fruits was measured with a +/$0.001 \mathrm{~g}$ balance. The pulps (epicarp + mesocarp) were removed with a knife and the core mass (seed + endocarp) was measured with the same balance. The pulp mass was calculated by difference. When

it was not possible to perform the measurements on just-harvested fruits, they were closed in plastic bags and stored at between 5 and $8^{\circ} \mathrm{C}$.

\section{Mass of the fruit and its parts. Dry mass}

Four hundred and nine fruits, divided in six lots, were washed with streaming water and submerged into distilled water at $45^{\circ} \mathrm{C}$ for approximately 20 minutes, to reduce the binding force between the pulp and endocarp. The pulps were removed manually; afterwards, pulp and core were dried in oven at $105^{\circ} \mathrm{C}$. The pulps were weighed and the fiber layer was removed manually from the seed, and then both were measured separately.

\section{Histological sections}

The sections were obtained from the tissues blocked in historesin and inked with blue Toluidine mounted in Apáthy's syrup (Kraus and Arduin, 1997). The anthocyanins in the pericarp were observed through microscope because of its natural color. The lipids were identified with Sudan Black B (saturated in solution of polyethylene glycol 400 and glycerin 10\% (1:1 v/v) (Tappi Test Method T222, 1998). The residue retained on the sieve was washed and dried, and treated with Jeffrey solution: chromic and nitric acid at $10 \%$ each. This process enabled the observation of its sclereids.

\section{Scanning Electron Microscopy (SEM)}

A fruit was washed with streaming water and submerged into distilled water at $45^{\circ} \mathrm{C}$ for approximately 20 minutes to reduce the binding force between the mesocarp and endocarp. Epicarp and mesocarp were removed manually, and the seed (with the fiber layer in the endocarp) was fixed to the sample holder, metalized and immediately observed. The samples of fibers were removed manually from the fiber bunches of the fiber layer. That fiber was not submitted to any treatment, except the metallization for SEM observation.

\section{Fiber layer registered by digital scanner}

After removing the epicarp and mesocarp, as described above, the remaining parts of the fruit were dried at $105^{\circ} \mathrm{C}$ and the fiber layer was removed manually. The upper and lower sides of the fiber layer were observed with an optical digital scanner.

\section{Quantification of the Extractives, Holocellulose, Cellulose and Lignin}

The water-soluble extractives were removed from $4.7 \mathrm{~g}$ of the fiber layer with $800 \mathrm{~mL}$ of water heated at $70^{\circ} \mathrm{C}$ for $2 \mathrm{~h}$. The same amount of clean water was used to repeat the process and then the sample was dried at $100^{\circ} \mathrm{C}$, when the extractives were determined by mass difference. The organic extractives were then removed with a solution of cyclohexene and ethanol $(1: 1)$ in a Soxhlet for $40 \mathrm{~h}$, and measured by mass difference. For Klason lignin determination the fibers were ground and sieved in a 30 mesh sieve. Subsequently, the TAPPI T2220m-98 (Tappi Test Method T222, 1998) procedure was used. The holocellulose amount was determined by the TAPPI T9m-54 (Tappi Test Method T9m-54, 1998) procedure, and cellulose in accordance with Browning (1967).

\section{Length of the fiber cells}

Some fiber bunches were submerged into paracetic acid (acetic acid and hydrogen peroxide 30v; 1:1) (Kraus and Arduin, 1997) (Franklin, 1945). The sample was maintained at $60^{\circ} \mathrm{C}$ and shaken periodically. After dispersion of the fiber cells, observed visually, they were washed with distilled water and submerged into a dye solution $(1: 1 \mathrm{v} / \mathrm{v})$ : $1 \mathrm{~g}$ of safranine in $100 \mathrm{~mL}$ of ethylic alcohol; $1 \mathrm{~g}$ of Astra blue in $100 \mathrm{~mL}$ of distilled water. A combination of safranin and astra blue was applied on some sections too. Fiber cells were placed on a thin glass plate and dispersed with glycerin and observed under the microscope (10x). The images of 100 fibers were registered and its length was measured with the software Image Tool for Windows v. 3.0 (Freeware, Texas University, 1995). The normality of the distribution was evaluated by the Kolmogorov-Smirnov test using the free software BioEstat v. 3.0. 


\section{RESULTS AND DISCUSSION}

The round açaí fruit presented $1 \mathrm{~mm}$ thick mesocarp formed by: 1. Epidermis; 2. External parenchyma; 3. External sclerenchyma; 4 . Storage parenchyma and; 5. Internal parenchyma.

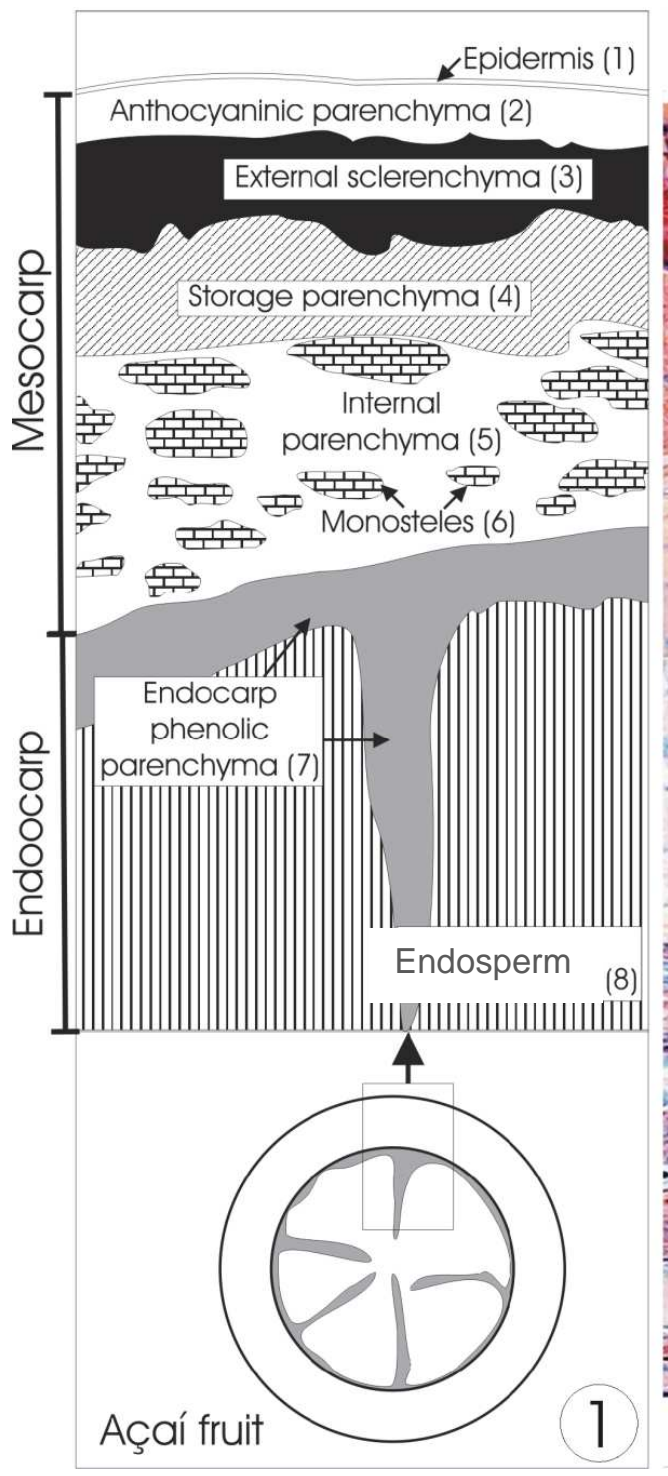

The epidermis and the external parenchyma (or anthocyaninic parenchyma) were rich in anthocyanin. The Storage Parenchyma was rich in lipid and the internal one suported the monosteles of the vascular system (Figs. 1 and 2).

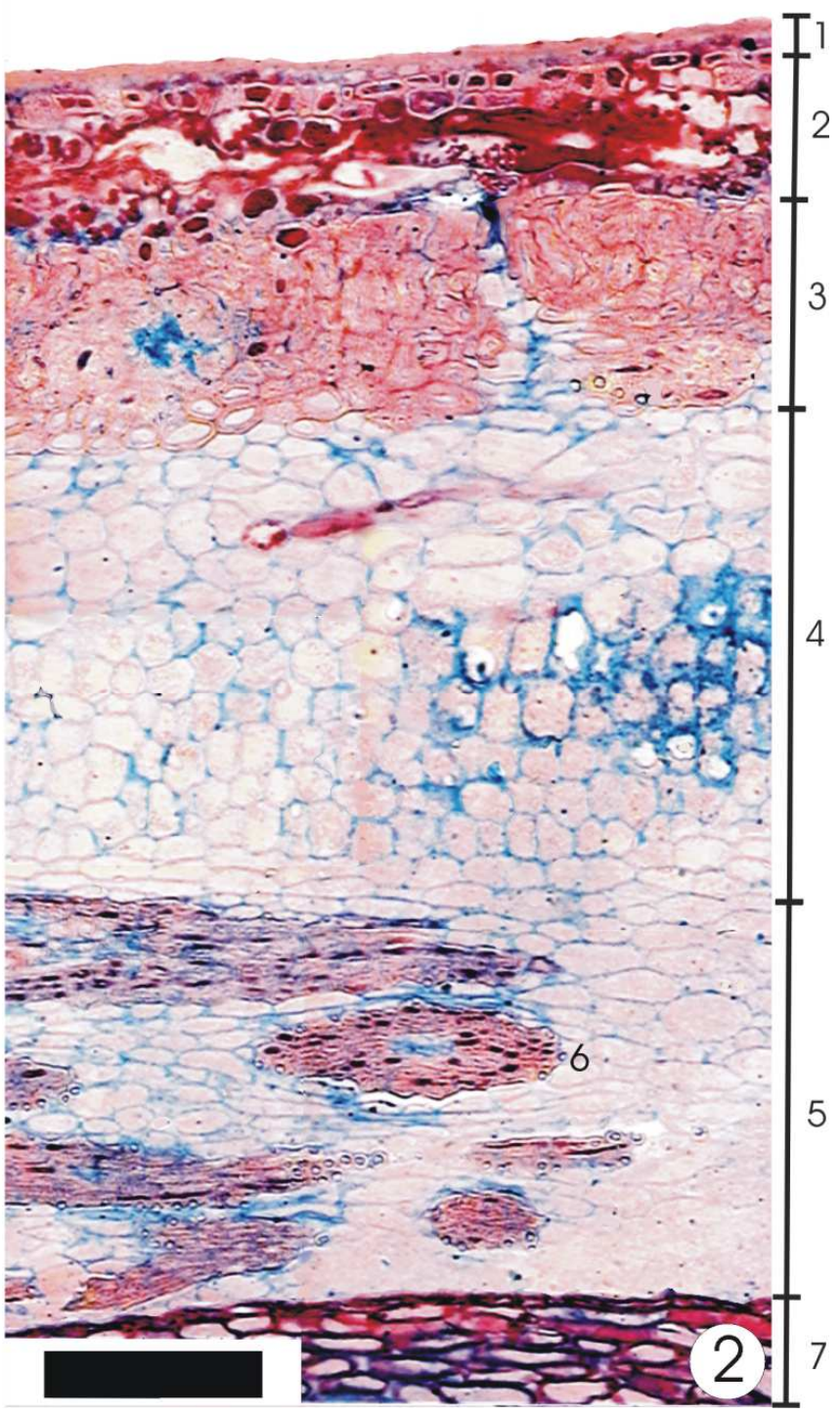

Figures 1-2 - Structural aspects of açaí fruit. 1) Diagram of fruit in transversal section; structures are indicated. 2- A general view of the pericarp, numbers are corresponded to the Fig. 1. Bar $=200 \mu \mathrm{m}$.

The pericarp presents at least $1-2 \mathrm{~mm}$ and surround a solid round body formed by sclereids. This body is the endosperm (Paula 1975). Portions of endocarp form strands into endosperm. They are brown color at fresh material and are colored by dark red in sections. Then, endocarp+endosperm was designated "core" here.

The epidermis is made by small cells covered externally by a cuticle (Fig. 3). Beneath it was a layer of sclereids present. The external 
parenchyma had at least 10 cell layers where anthocyanins were accumulated. Free-hand cut material showed the antocyanins in vacuole and it was uniform. In the fixed materials, the anthocyanins (a phenol compound) presented a granulous aspect.

The external sclerenchyma (Fig. 3) was formed by live cells with thick secondary walls. Pit channels were not easily observed. The storage parenchyma (Fig. 4) was formed by three to six layers of elongated cells at anticlinal (perpendicular to the fruit surface) orientation. The fat bodies, colored by Sudan Black B, were unequally distributed in the tissue (Fig. 5). The internal parenchyma was formed by several cell layers elongated at periclinal (parallel to the fruit surface) orientation (Figs. 2 and 5); storage substances were not present but could be seen the vascular system constituted by monosteles (Fig. 6 ), which was a vascular bundle with xylem and phloem, surrounded by fiber cells and endodermis. The fiber cells were alive in açaí fruit but dead for many species of monocotyledons. The entire vascular system of the açaí fruit corresponded to the fiber layer (Fig. 9), obtained after depulping and drying. Internal parenchyma was the inner zone of the mesocarp.

The endocarp presented a phenolic parenchyma
(Fig. 7) made by anticlinal and periclinal cell layers across the solid mass of sclerenchyma (Fig. 8). The phenolic parenchyma presented a brown color after depulping and the sclerenchyma was white. Sclerenchyma cells were alive. Its walls presented clearly observed pit channels and were poorly stained. The pulp was the detached part of the fruit during the processing: epidermis, external parenchyma, sclerenchyma, and part of the storage parenchyma. The main residues from the açaí fruit depulping included the solids retained in the sieve, the fiber layer, and the seed. The solids found in the sieve corresponded to around $4.5 \%$ on the dry matter basis, the seed corresponded to $75.8 \%$, and the fiber layer to $5.3 \%$ (Table 1). According to Yuyama et al. (2002a), the seed corresponded to $70 \%$ and the pulp $25 \%$.

The mass retained on the sieve contained anthocyanins and other components of the drink. There is no detailed study on this subject matter. The treatment of its dry mass with Jeffrey solution showed that it was formed mainly by sclereids, found in the sclerenchyma of the pulp, which was removed together with the two parenchymas and the epidermis during the processing. The epidermis and the external parenchyma were the main source of the anthocyanins and the internal parenchyma of the lipids.

Table 1 - Fresh and dry mass of the fruit and its parts.

\begin{tabular}{|c|c|c|c|c|c|c|c|c|c|}
\hline & \multirow{2}{*}{ Fruit (g) } & \multicolumn{2}{|c|}{ Pulp } & \multicolumn{2}{|c|}{ Core } & \multicolumn{2}{|c|}{ Seed } & \multicolumn{2}{|c|}{ Fiber layer } \\
\hline & & (g) & $\%$ & (g) & $\%$ & (g) & $\%$ & (g) & $\%$ \\
\hline Fresh & $\begin{array}{c}1.46 \\
(0.26)\end{array}$ & $\begin{array}{c}0.366 \\
(0.075)\end{array}$ & 25 & $\begin{array}{c}1.09 \\
(0.21)\end{array}$ & 74.6 & -- & -- & -- & \\
\hline Dry & $\begin{array}{c}0.892 \\
(0.037)\end{array}$ & $\begin{array}{c}0.168 \\
(0.006)\end{array}$ & 18.8 & $\begin{array}{c}0.722 \\
(0.035)\end{array}$ & 80.9 & $\begin{array}{c}0.676 \\
(0.031)\end{array}$ & 75.8 & $\begin{array}{c}0.047 \\
(0.006)\end{array}$ & 5.3 \\
\hline Humidity & $38.9 \%$ & $54.1 \%$ & & $33.8 \%$ & & & & & \\
\hline
\end{tabular}

The values between parenthesis are the Standard Deviations. Pulp = epiderm + part of the internal parenchyma. Core $=$ Seed + part of the internal parenchyma. Fiber layer: vascular tissue in the internal parenchyma.

Yuyama et al. (2002b) measured the soluble and insoluble fibers in açaí juice. The drink samples were obtained from the fruits of five different spots of the Solimões river basin. The mean insoluble and soluble fibers of juice (dry matter) were $5.11 \mathrm{~g} \cdot 100 \mathrm{~g}^{-1}$ and $0.82 \mathrm{~g} \cdot 100 \mathrm{~g}^{-1}$, respectively. The depulping process scratched the internal parenchyma, probably an importat source of fibers, especially the insoluble one removed from the fiber layer. A soft depulping process produced a less viscous drink. Rogez (2000) measured the total amount of fibers in the juice, obtaining the mean value of $25.22 \mathrm{~g} \cdot 100 \mathrm{~g}^{-1}$ dry matter. Although both authors used the same procedure for the sample preparations (a vertical depulping machine), it was possible that the details were different: the amount of water used for depulping, processing time, and the source of the fruits: the first author obtained the fruits from West Amazon, and the second one from East Amazon. Aguiar (1996) determined the total fiber of the mesocarp as $32.7 \mathrm{~g} \cdot 100 \mathrm{~g}^{-1}$ (dry matter), measuring directly from the fruit, not from the juice. 

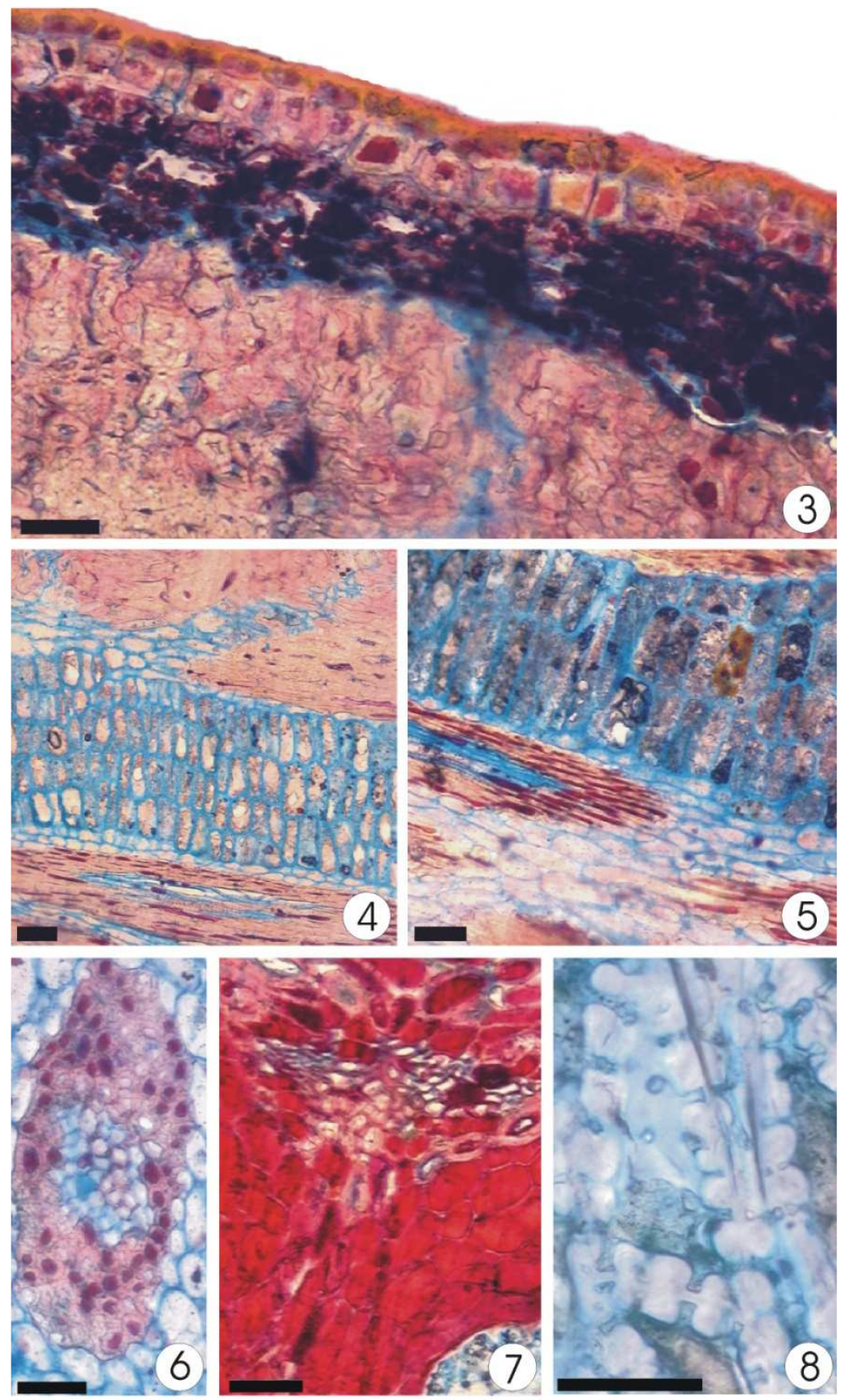

Figures 3-8 - Details of histological views of pericarp structures 3) Epidermis, anthocyaninic parenchyma _ the dark round bodies are the antocyanin remaining after histological process, and external sclerenchyma _ the cells present a thick secondary wall and protoplast is alive. 4) Storage parenchyma, gross view. 5) A detail of storage parenchyma with lipid globules (dark bodies). 6) Aspect of a monostele; many monocotyledons present a vascular system formed by individual bundles with alive pericycle fibers $(\mathrm{Fb})$, xylem $(\mathrm{X})$ and phloem $(\mathrm{ph})$. Each monostele form a strong fiber and all monosteles of a fruit may remain after destruction of internal parenchyma cells (fig 9). 7) Aspect of endocarp phenolic parenchyma; its natural color is brown, but it is strongly colored by safranin. Monosteles may be present in it (m). 8) Aspect of endosperm sclerenchyma; the cells present a thick poorly colored secondary wall, but their protoplasts are alive and darker. Pit channels are observed in secondary walls. All bars $=100 \mu \mathrm{m}$. 
After depulping, the endocarp presented a smooth surface through which some fiber bunches emerged. That surface, after vacuum metallization, and observed through a scanning electronic microscope, revealed the arrangement of the bundle of fibers (the vascular system): parallel stripes at different height levels. The vascular system had a monostelical structure (Ogura, 1972) and the monosteles form the fiber. The transversal view of a vascular bundle in Figure 6 shows the periciclic fiber cells, the phloem and the xylem.

After drying the core at $105^{\circ} \mathrm{C}$, the cells of internal parenchyma were disintegrated but the fibers remained, and could be easily detached from the core (Fig. 9). The fiber had about $80 \mu \mathrm{m}$ diameter and pit point channels were observed crossing the fiber cell wall (Fig. 10). The length of a fiber was around 20 millimeters, and displayed a relatively high content of Klason Lignin (33\%), very close to the coconut fiber. The cellulose content was relatively low, 33\%, compared to most usual values, from 28 to $96 \%$ (Rowell et al., 2000). The bunches also contained $37 \%$ of hemicellulose, $7 \%$ of extractives in water and $1 \%$ of organic extractives.

Unpacked fiber cells were obtained by immersing the fiber into a peroxide solution (Kraus and Arduin, 1997). This was a very specific solution for lignin dilution and the class of peracids had been used to substitute the chlorine reagents in Elemental Clorine Free sequences and had been useful in Total Chlorine Free sequences. The oxidant potential of peracids is very high and the pulps bleached with this present good resistance, indicating low level of cellulose degradation (Brasileiro et al., 2001). The fiber cells obtained by this method presented mean length of $580 \mu \mathrm{m}$ (SD $212 \mu \mathrm{m}$ ) and midline $560 \mu \mathrm{m}$ (Fig. 11). According to Kolmogorov-Smirnov test (BioEstat v. 3.0), the length distribution was normal.

A potential application to reduce the fiber layer residues is its application in composites. Several researchers have prepared and evaluated the properties of composites based on natural fibers for diverse applications. Polymer composites have been developed using short and long fibers, chips, flakes, strands, wood pulp fiber, wood flour, etc (Mohanty and Misra, 1995) (Bledzki and Gassan, 1999) (Martins and Mattoso, 2004). Mohanty and
Misra (1995) reviewed the jute-reinforced thermosets, thermoplastics, and rubber-based composites, whereas Bledzki and Gassan (1999) reviewed the composites reinforced with cellulosebased fibers. By embedding the natural reinforcing fibers, e.g., flax, hemp, ramie, jute, etc., into biopolymeric matrix made of derivatives from cellulose, starch, lactic acid, etc., new fiberreinforced materials called biocomposites have been created and continue to be developed. Biocomposites containing natural fibers and biodegradable matrices have been patented for applications such as building materials (Mishra et al., 2004).

The structure and properties of these natural fibers depend upon several factors such as age, source, microfibrils, straightness, diameter, and chemical constituents. Since these fibers have small crosssections and cannot be directly used in engineering applications, they are embedded in matrix materials to form the fiber composites. The matrix serves as a binder to fasten the fibers together and transfer loads to the fibers. In order to develop and promote these natural fibers and their composites, it is necessary to understand their physicomechanical properties. Sisal fiber, for example, has lengths of less than $60 \mathrm{~cm}$ up to more than 111

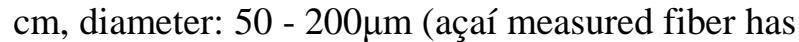
around $80 \mu \mathrm{m}$ ) and its fiber cells range from $1500 \mu \mathrm{m}$ to $4000 \mu \mathrm{m}$ (while açaí ranges from $200 \mu \mathrm{m}$ to $1050 \mu \mathrm{m}$ ), with a diameter ranging between 10 to $30 \mu \mathrm{m}$ (Rowell et al., 2000). Its Young modulus is $10 \mathrm{GPa}$, tensile strength $445 \mathrm{MPa}$, and deformation before rupture of $9 \%$. Descending on the scale, sisal microfibrils range from $0.1 \mu \mathrm{m}$ to $0.2 \mu \mathrm{m}$, and recent studies have demonstrated attempts for applications.

Another potential use for fiber layers is as substrate for yielding the ligninolytic mushrooms of the gender Pleurotus ( $P$. sajor-caju, $P$. ostreatus, $P$. estreatoroseus), used in cuisine and tested in other fields. Barton et al. (2002), for example, used $P$. ostreatus as a source of laccase, a copper-containing polyphenol oxidase, to determine $\mathrm{O}_{2}$ in water, and Leite et al. (2003) used that mushroom to obtain a biosensor based on carbon paste to determine the catecholamines adrenaline and dopamine in pharmaceutical formulations. 

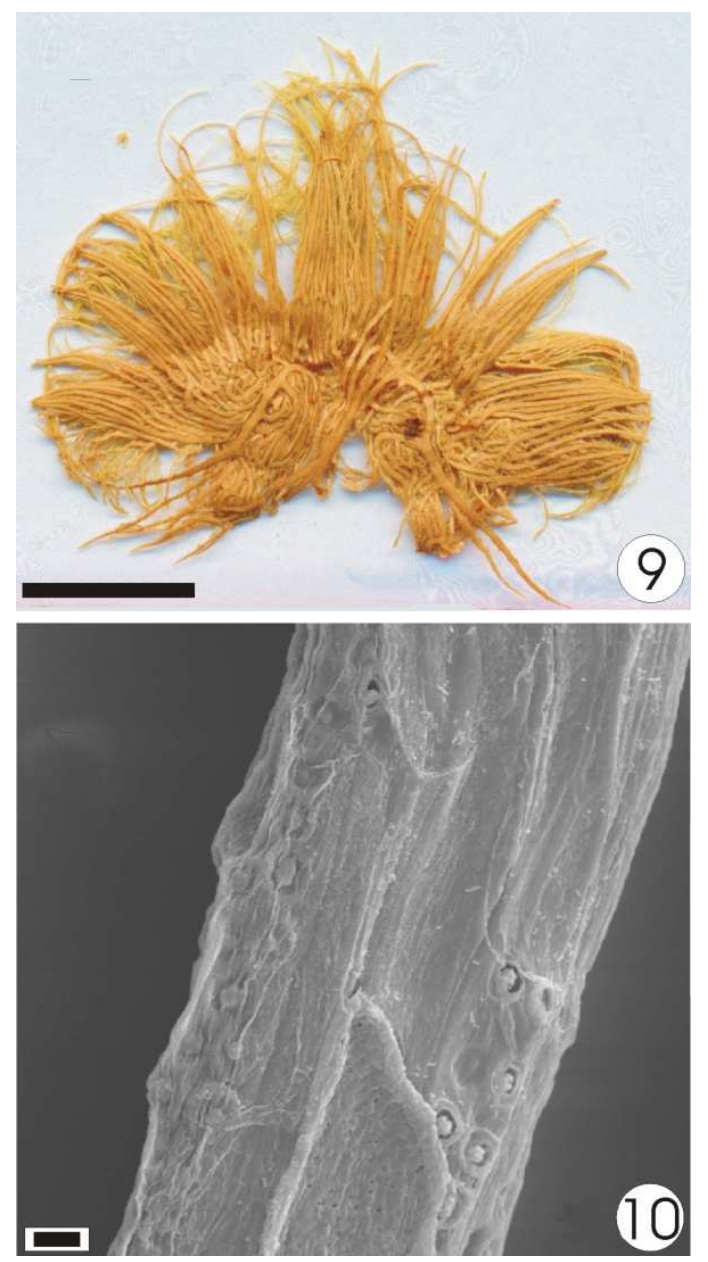

Figure 9-10 - Fibers (= monosteles separated from internal parenchyma). Fig. 9: External face of the conducting tissue (fiber layer) dried on oven at $105^{\circ} \mathrm{C}$. Bar $=1 \mathrm{~cm}$. Fig. 10. A fiber observed by Scanning Electron Microscope _ the pit channels with plasmodesms are clearly observed. Bar $=10 \mu \mathrm{m}$.

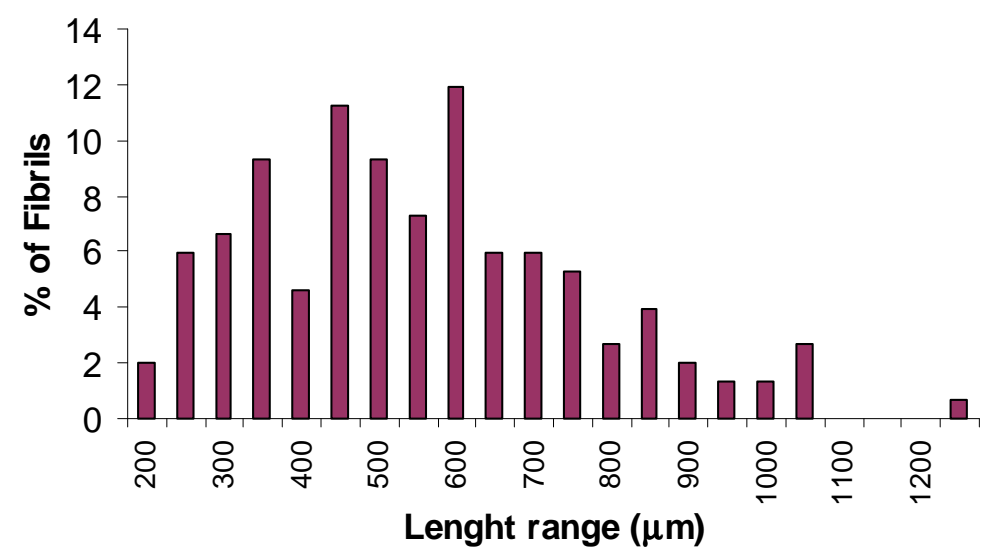

Figure 11 - Fibril lengths from a sample of 150 fibrils. 


\section{CONCLUSIONS}

From the results it could be concluded that the pericarp was compartmentalized and presented an epidermis and beneath it there was a parenchyma that contained red anthocyanins. The external sclerenchyma was the main source of the fragmental residues retained on the sieve. The storage parenchyma was rich in fatty acids and the internal parenchyma included the monosteles that formed the fiber layer. The endosperm was formed by a solid mass of sclereids and some phenolic parenchyma rays. The diameter of the fibers was approximately $80 \mu \mathrm{m}$ and its fibrils range was from $200 \mu \mathrm{m}$ to $1050 \mu \mathrm{m}$. Some of the alternatives for agroindustry residues reduction include its use in composites.

\section{ACKNOWLEDGEMENTS}

The authors would like to thank Dr. Fernanda Ilkiu-Borges Souza who gave many suggestions, to Dr. Joaquim Gomes and Dr. Luíz H. C. Mattoso for some equipments, to Dr. Douglas Britto for the chemical analysis and to Amazonfrut for their support.

\section{REFERENCES}

Aguiar J.P.L., (1996), Tabela de composição de alimentos da Amazônia. Acta Amaz. 26, 121126.

Aguiar M.O., Mendonça M.S. de., (2003), Morfoanatomia da semente de Euterpe precatória Mart. (Palmae). Rev. Bras. Sementes, 25, 37-42.

Barton S.C., et al., (2002), Electroreduction of O2 to water at $0.6 \mathrm{~V}$ (SHE) at $\mathrm{pH} 7$ on the 'wired' Pleurotus ostreatus laccase cathode, Biosens. Bioelec. 17, 1071-1074.

Bledzki A.K., Gassan J., (1999), Composites reinforced with cellulose based fibers. Prog. Polym. Sci. 24, 221-274.

Brasileiro L.B., et al., (2001), A utilização de perácidos na deslignificação e no branqueamento de polpas celulósicas. Quím. Nova, 24, 819-829.

Browning B.L., (1967), Methods of wood chemistry, John Wiley, New York.
Brunderett M. C., et al., (1991), Efficient lipid staining in plant material with Sudan Red 7B or Fluoral Yellow 088 in polyethylene glycolglycerol. Biotech. Histochem. 66, 111-116.

Coïsson J.D., et al., (2005), Euterpe oleracea juice as a functional pigment for yogurt, Food Res. Intern. 38, 893-897.

Costa F. de A., et al., O processamento de frutas no nordeste paraense e região metropolitana de Belém: um arranjo produtivo emergente. (2004) [Rio de Janeiro]: IE-UFRJ. Available at <www.redesist.ie.ufrj.br. Downloaded at 2006.

Franklin G.L., (1945), Preparation of thin sections of synthetic resins and wood-resin composites, and a new macerating method for wood, Nature $155,3924$.

Freckleton R.P. et al., (2003), Predicting the impacts of harvesting using structured population models: the importance of densitydependence and timing of harvest for a tropical palm tree. J. Appl. Ecol. 40, 846-858.

Kraus J.E., Arduin M., (1997), Manual básico de métodos em morfologia vegetal. EDUR: Rio de Janeiro.

Leite O.D., et al., (2003), Determination of catecholamines in pharmaceutical formulations using a biosensor modified with a crude extract of fungi laccase (Pleurotus ostreatus). J. Braz. Chem. Soc. 14, 297-303.

Martins M.A,. Mattoso L.H.C., (2004), Short Sisal Fiber-Reinforced Tire Rubber Composites: Dynamic and Mechanical Properties, J. Appl. Polym. Sci. 91, 670-677.

Mishra S., et al., (2004), A Review on Pineapple Leaf Fibers, Sisal Fibers and Their Biocomposites. Macromol Mater Eng, 289, 955974.

Mohanty A.K., Misra M., (1995), Studies on jute composites - a literature review. Polym. Plast Technol. Eng. 34, 729-792.

Murrieta R.S.S. et al., (1999), Food consumption and subsistence in three caboclo populations on Marajó Island, Amazonia, Brazil, Human Ecology. 27, 455-475.

Nogueira O.L., (2000), Regeneração e Crescimento Vegetativo de Açaizeiros (Euterpe oleracea) em Área de Várzea do Estuário Amazônico, Rev. Bras. Frutic. 22, 323-328. 
Nogueira O.L., Conceição H.E.O. da., (2000), Análise de Crescimento de Açaizeiros em Áreas de Várzea do Estuário Amazônico, Pesq. Agropec. Bras. 35, 2167-2173.

Ogura, Y. (1972), Comparative anatomy of vegetative organs of pteridophytes. Gerbrüder Borntraeger, Berlim.

Paula J.E. de, (1975), Anatomia de Euterpe oleracea Mart. (Palmae da Amazônia), Acta Amaz. 5, 265-278.

Rogez H., (2000), Açaí: Preparo, composição e melhoramento da conservação. EDUFPA, Belém,.

Rowell R.M., et al., (2000), Characterization and factors affecting fiber properties. In Frollini E., Leão A. and Mattoso L.H.C. (edts): Natural polymers and agrofibers based composites: preparation, properties and applications, USP/IQSC Embrapa/CNPIA Botucatu/UNESP, São Carlos.

Santana A.C. de, (2006), Dinâmica espacial da produção rural do Estado do Pará: referências para o desenvolvimento sustentável. Belém, PA.

Tappi Test Method T222 om-98, (1998), Acidinsoluble lignin in wood and pulp, Tappi Press, Atlanta.

Tappi Test Method T9m-54, (1998), Holocellulose in wood, Tappi Press, Atlanta.
Tjong S.C., Xu Y., Meng Y.Z., (1999), Composites based on maleated polypropylene and methyl cellulosic fiber: Mechanical and thermal properties. J. Appl. Polym. Sci. 72, 1647-1653.

Wilcox, D.; Dove, B.; McDavid, D.; Greer, D. UTHSCSA: Image Tool for Windows ${ }^{\circledR}$. Version 3. San Antonio: University of Texas health Science Center, 2002. Disponível em: <http://ddsdx.uthscsa.edu/dig/itdesc.html>. acesso em: 15 jul. 2009.

Yuyama L.K.O., et al., (2002a), Açaí como fonte de ferro: mito ou realidade, Acta Amaz. 32, 521525.

Yuyama L.K.O., et al., (2002b), Quantificação de fibra alimentar em algumas populações de cubiu (Solanum sessiliflorum Dunal), camu-camu (Myrciaria dubi (H.B.K) Mc Vaugh) e açaí (Euterpe oleracea Mart.), Acta Amaz. 32, 491497. 